\title{
Towards an improved lithostratigraphic subdivision of the Chalk Group in the Netherlands North Sea area - A seismic stratigraphic approach
}

\section{A.S. van der Molen ${ }^{1,3} \&$ Th.E. Wong ${ }^{1,2}$}

1 Faculty of Earth Sciences, Utrecht University, Budapestlaan 4, 3584 CD Utrecht, the Netherlands.

2 TN0 Built Environment and Geosciences - National Geological Survey, Princetonlaan 6, 3584 CB Utrecht, the Netherlands.

3 Corresponding author, present address: A/S Norske Shell, P0 Box 40, N-4098, Tananger, Norway.

Manuscript received: September 2006; accepted: January 2007

\begin{abstract}
In the Netherlands North Sea area, the Chalk Group has thus far been subdivided into the Cenomanian Texel Formation, the Turonian to Maastrichtian Ommelanden Formation and the Danian Ekofisk Formation. This paper describes the attempt to arrive at a more detailed lithostratigraphic subdivision for this area, particularly of the 0mmelanden Formation. To this end, a seismic stratigraphic analysis was carried out on a regional 2D and 3D seismic dataset. The Chalk Group was subdivided into eleven seismic stratigraphic sequences, named CK1 through CK11, based on the mapping and correlation of unconformities. The identified seismic sequence boundaries were used as the main chronostratigraphic markers in the Chalk Group interval. The seismic dataset was subsequently expanded with well log data of 45 boreholes. These were tied to the seismic dataset by constructing a synthetic seismogram for each borehole, after which the seismic sequence boundaries were noted and correlated on the logs. Finally, micropaleonthological data available in 15 boreholes were used to date the seismic sequences. The sequences were interpreted to be of Cenomanian (CK1), Turonian (CK2), Coniacian (CK3), Santonian (CK4), Early Campanian (CK5; CK6), Middle to Late Campanian (CK7), Early Maastrichtian (CK8; CK9), Late Maastrichtian (CK10) and Danian (CK11) age. The seismic units recognised in this study were compared with formal lithostratigraphic units defined in the Chalk Group in the surrounding North Sea sectors. Based on this comparison, a revision of the formal lithostratigraphic scheme, recognising Tor Formation and Herring Formation equivalents, is suggested for the Netherlands North Sea area.
\end{abstract}

Keywords: Chalk Group; chronostratigraphy; Late Cretaceous; lithostratigraphy; Southern North Sea; seismic stratigraphy

\section{Introduction}

In north-western Europe, the Upper Cretaceous to Lower Cenozoic Chalk Group forms an almost purely calcitic succession, reaching a maximum thickness of over $2000 \mathrm{~m}$ in the Central Graben and the Münsterland Basin (Fig. 1). These deposits represent a period when a high eustatic sea level, coinciding with low detrital influx, permitted pelagic sedimentation on the continental shelves (Hancock, 1975; Ziegler, 1990; Surlyk et al., 2003). The settlement of calcareous ooze (almost entirely consisting of coccoliths) from suspension in the water column formed the primary sedimentary mechanism (Hancock, 1975; Kennedy, 1987; Surlyk et al., 2003).

The sediments of the Chalk Group in north-western Europe were deposited on a sea floor that initially consisted of several intra-basinal highs and lows of Late Jurassic to Early Cretaceous age (Fig. 2). During deposition, the area underwent a complex tectonic evolution, whereby early Mesozoic structural elements were reactivated by a number of compressional phases. As a result, the thickness of the Chalk Group varies greatly throughout the area (Fig. 1). The Dutch Central Graben and Broad Fourteens Basin were inverted during this period, leading to deep erosion, and even removal, of the Chalk Group succession (Van Wijhe, 1987; Ziegler, 1990; Dronkers \& Mrozek, 1991; De Jager, 2003).

Stratigraphic studies of the Chalk Group in the Netherlands have traditionally focussed on the south-west of the country and adjacent areas in Belgium and Germany. Here, the Chalk Group is developed as a basin-margin facies and intercalations of coarse bioclastic limestones, sandstones and shales occur 


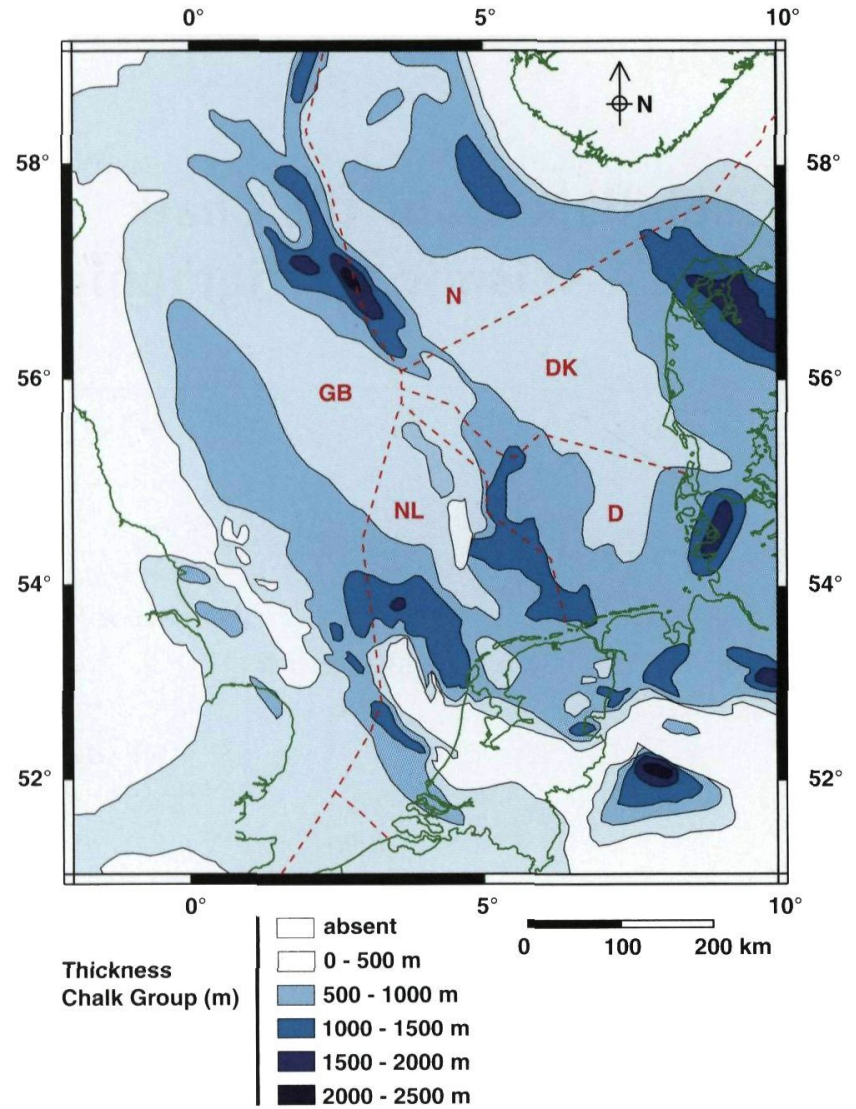

Fig. 1. Thickness of the Chalk Group in the central and southern North Sea area (after: Ziegler, 1990). The North Sea offshore sectors are outlined in red (NL: Netherlands, D: Germany, DK: Denmark, N: Norway, GB: Great Britain).

(e.g. Felder, 1975; Felder et al., 1985; Bless et al., 1987; Gras \& Geluk, 1999). The stratigraphy of open marine chalks was studied by Herngreen et al. (1996) from boreholes located in the north-east of the Netherlands. This facies is similar to that encountered throughout the North Sea area.

In the Netherlands offshore, the Chalk Group remains one of the least studied stratigraphic intervals due to its limited significance as a hydrocarbon reservoir. Consequently, both cored sections and biostratigraphical data are scarce here, leaving a rather crude subdivision into three lithostratigraphical units. These are the Cenomanian Texel Formation, the Turonian to Maastrichtian Ommelanden Formation and the Danian Ekofisk Formation (Fig. 3; Van Adrichem Boogaert \& Kouwe, 1994). To improve this subdivision, a seismic stratigraphic analysis of the interval was done on a regional 2D and 3D seismic dataset (Fig. 4).

By identifying and tracing unconformities and their associated correlative conformities in seismic data, a stratigraphic interval can be subdivided into chronostratigraphically significant seismic sequences (Mitchum et al., 1977b; Vail et al., 1977b). Following a similar approach, the Chalk Group in the Danish offshore was subdivided into six seismic sequences by Nygaard et al. (1989) and eight seismic sequences by Andersen et al. (1990). In this paper, we present a seismic stratigraphical

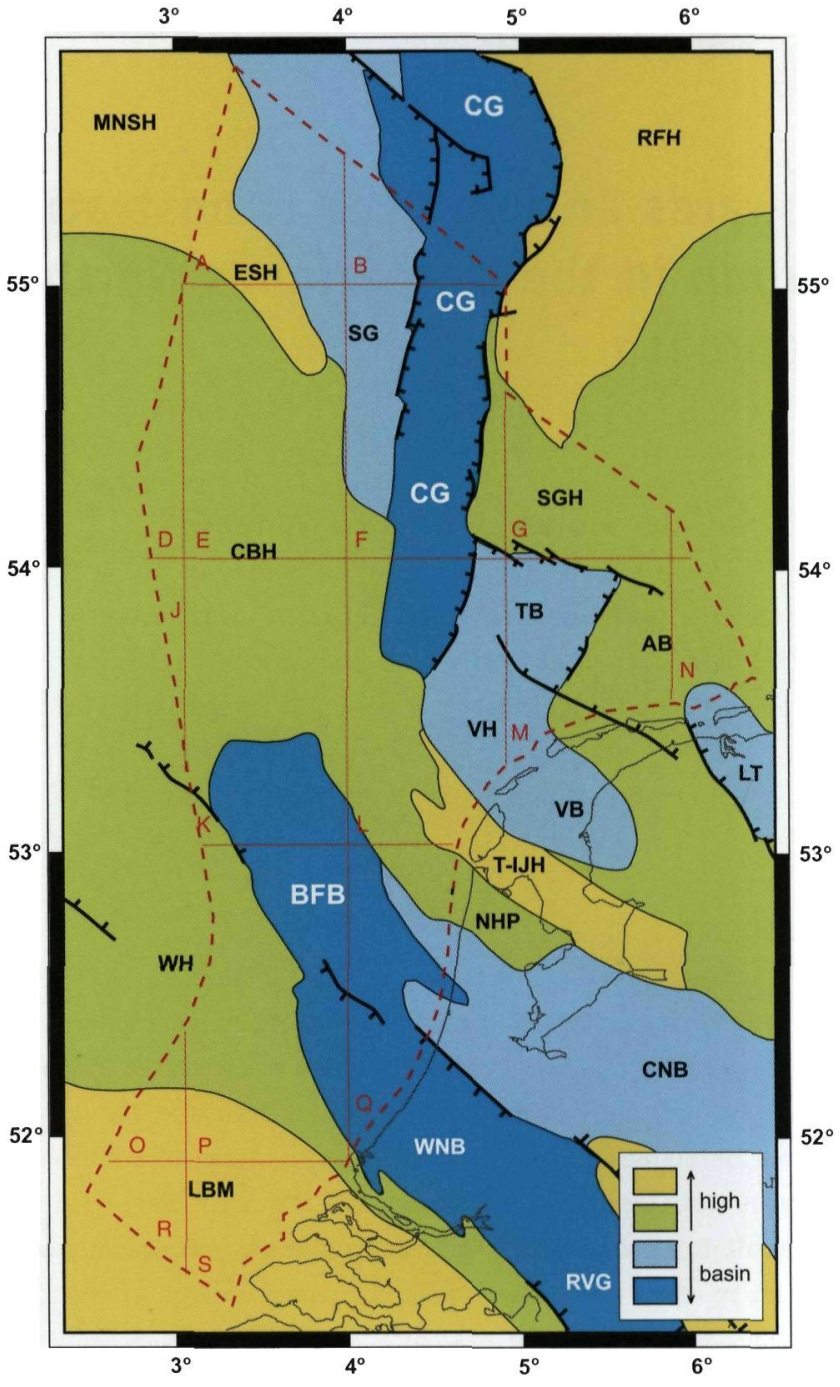

Fig. 2. Mesozoic structural elements of the Netherlands North Sea. The Early Mesozoic southern Central Graben, Broad Fourteens Basin and West Netherlands Basin were inverted during the Late Cretaceous and early Cenozoic, leading to erosion or non-deposition of chalk in these areas. In turn, former highs such as the Cleaver Bank High and Schill Grund High subsided during this period, leading to the accumulation of a thick chalk layer (Van Wijhe, 1987; Ziegler, 1990; Dronkers \& Mrozek, 1991; De Jager, 2003). MNSH: Mid North Sea High, CG: Central Graben, RFH: RynkøbingFyn High, ESH: Elbow Split High, SG: Step Graben, CBH: Cleaver Bank High, SGH: Schill Grund High, TB: Terschelling Basin, AB: Ameland Block, VH: Vlieland High, VB: Vlieland Basin, LT: Lauwerszee Trough, T-IJH: Texel IJselmeer High, WH: Winterton High, BFB: Broad Fourteens Basin, NHP: North Holland Platform, WNB: West Netherlands Basin, CNB: Central Netherlands Basin, LBM: London Brabant Massif. Quadrants are outlined in red.

subdivision of the Chalk Group into eleven sequences. The results support the existing formal partitioning of the Texel and Ekofisk Formations in the study area, but suggest a further subdivision of the Ommelanden Formation. The identified seismic sequences were classified according to seismic facies characteristics such as reflector configuration, amplitude, frequency and continuity. 


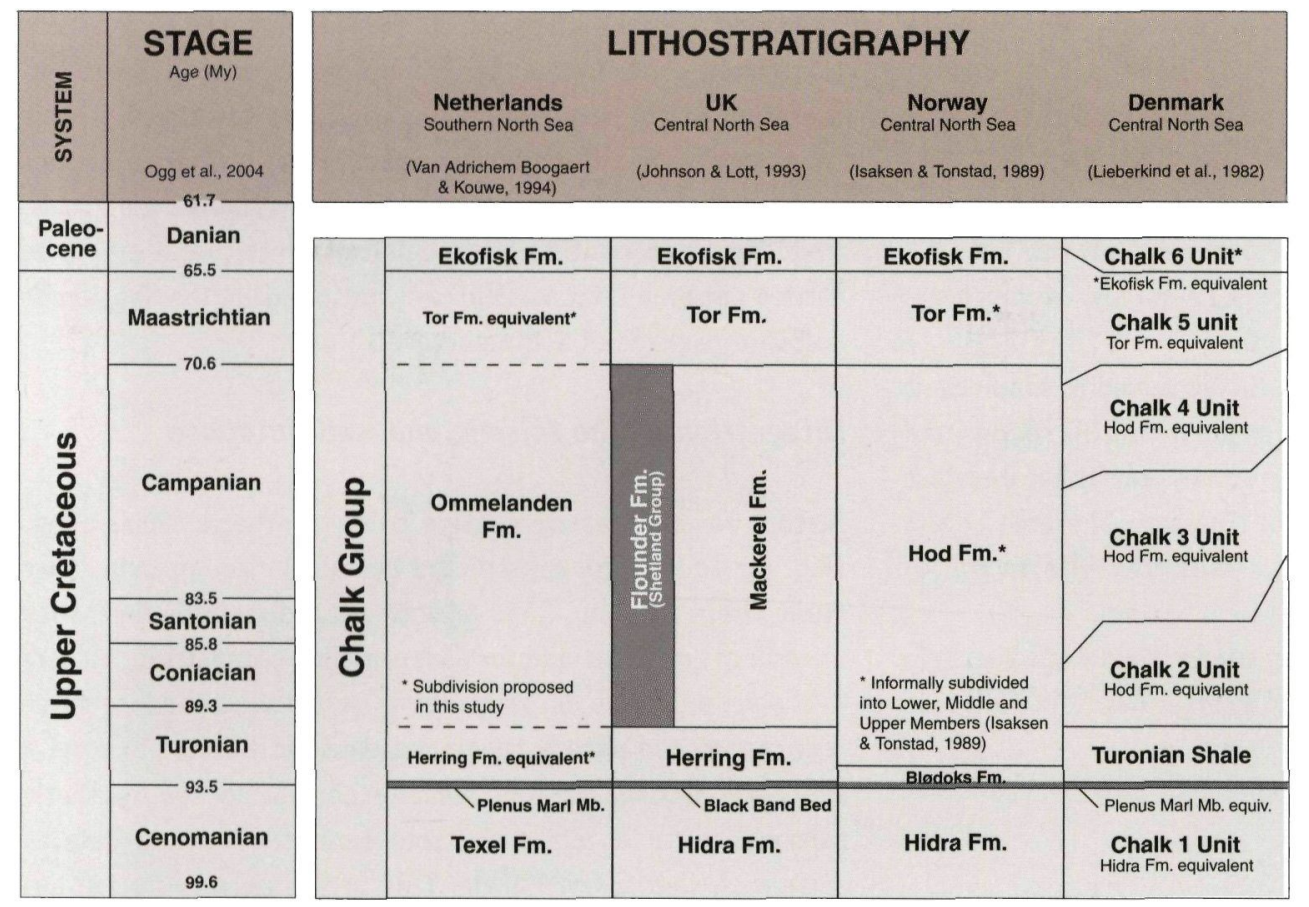

Fig. 3. Lithostratigraphic subdivision of the Chalk Group in the Dutch, British, Norwegian and Danish sectors of the North Sea (Lieberkind et al., 1982; Isaksen \& Tonstad, 1989; Johnson \& Lott, 1993; Van Adrichem Boogaert \& Kouwe, 1994). Because the sediments of the Chalk Group form only a minor hydrocarbon reservoir in the Netherlands North Sea area, the interval received less attention compared to the surrounding sectors. As a result, a fairly basic lithostratigraphic subdivision of the Chalk Group exists for the study area.

The seismic database was supplemented with well logs of 45 boreholes (Fig. 4). After construction of the synthetic seismograms to integrate the seismic and well database, the seismic sequence boundaries were identified and correlated between the wells. This well-log correlation supported the seismic interpretation, allowing the sequences to be characterised by log response and dated using micropaleonthological data from several boreholes (Fig. 4). Finally, log correlations with wells from the Danish, British and Norwegian North Sea allowed a comparison of the results of this study with the formal lithostratigraphic schemes used in the neighbouring countries.

\section{Dataset and methods}

\section{Seismic reflection data}

The backbone of the seismic dataset was formed by the NOPEC SNST83 and SNST87 2D-surveys (Fig. 4). Together, these surveys cover the entire Netherlands offshore area with a spacing of about 20 to 40 kilometres between consecutive lines. The shot point (SP) interval of the SNST83-survey varies between $18 \mathrm{~m}$ and $28 \mathrm{~m}$ (avg. $25 \mathrm{~m}$ ), with the exception of line SNST83-07 (SP interval: $50 \mathrm{~m}$ ). In the SNST87-survey, the SP interval is a constant $25 \mathrm{~m}$.

Fig. 4. Overview of the study area and dataset used. The lithostratigraphic subdivision of the Chalk Group was reconstructed by interpretation and correlation of $2 D$ seismic data (dark grey), 3D seismic data (light grey: $C G=$ Central Graben, VOA = Vlieland offshore area), well logs of 45 boreholes and biostratigraphical data of 15 boreholes, ten of which are represented in Fig. 8 (in red). The coloured annotations refer to subsequent figures in this paper.

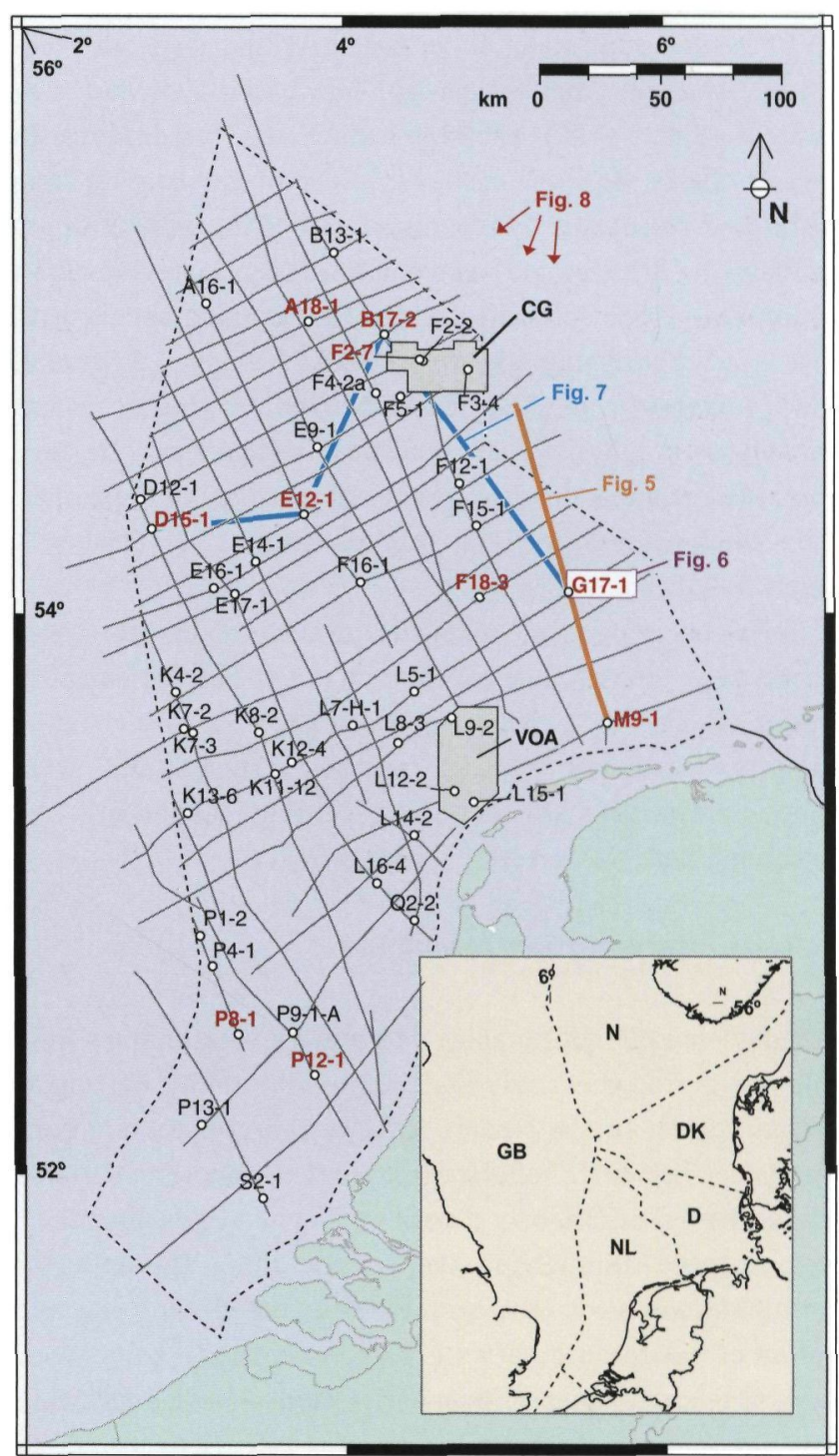


To add seismic imaging detail in a structurally complex area, two 3D-seismic surveys with a combined area of $550 \mathrm{~km}^{2}$ (Indicated ' $\mathrm{CG}^{\prime}$ in Fig. 4) were studied in the Dutch Central Graben. The area covers the offshore quadrants F2 and F3. The F2-survey is about $100 \mathrm{~km}^{2}$ in size, with a common depth point (CDP) spacing of both inlines and crosslines ('bin size') of 12.5 metres. It partly overlaps the adjacent F3-survey, which covers $500 \mathrm{~km}^{2}$ and has a bin size of $25 \mathrm{~m}$.

The Vlieland offshore 3D seismic survey served to supplement the sparse 2D seismic dataset in this area. This 3D survey area consists of a $1000 \mathrm{~km}^{2}$ 3D-seismic survey and is located just north of the Wadden Sea island of Vlieland. The area covers the offshore blocks L9, L12 and L15 (indicated 'VOA' in Fig. 4) and has a bin size of $25 \mathrm{~m}$.

Both 3D surveys were previously used for a detailed seismic facies analysis of the Chalk Group interval (Van der Molen et al., 2005).

\section{Well data}

The well log dataset consisted of gamma-ray and sonic logs of 45 boreholes, supplemented with density and resistivity logs where available. The gamma-ray log, which indicates clay content (Rider, 1996), shows generally very low readings in pelagic chalks. However, small variations in clay content have been used to support the identification of intra-Chalk Group units in the British and Norwegian North Sea sectors (Isaksen \& Tonstad, 1989; Johnson \& Lott, 1993). Sonic and density logs measure primarily porosity in chalks (Campbell \& Gravdal, 1995; Anderson, 1999). Sonic and density logs thus document variations in physical and chemical compaction, in turn controlled by burial depth, depositional process, overpressuring, pore fluid composition and original grain size (Brasher \& Vagle, 1996).

Industrial reports of micropaleonthological dating, based on benthic foraminifera taken from ditch cutting samples, were available for 15 wells (Fig. 4). Of these, 9 wells could be directly correlated to the seismic dataset and were subsequently used to date the seismic sequences. The remaining data was used for reference.

\section{Seismic interpretation techniques}

Standard seismic stratigraphy interpretation techniques were followed during this study (Mitchum et al., 1977c; Bertram \& Milton, 1996). In the seismic surveys, reflector terminations were identified first. Reflector terminations following surfaces within the succession, indicative of stratigraphic unconformities, were mapped throughout the seismic grid. The reflector configurations along the surface were noted to study the nature of the unconformity, i.e. onlap or erosional truncation. A set of seismic sequences boundaries were identified following this procedure. Where no reflector terminations could be identified, parallel reflectors, which were assumed to represent correlative conformities, were followed to extend the interpretation of the sequence boundaries. The identified seismic sequences were subsequently classified according to seismic facies characteristics such as reflector configuration, amplitude, frequency and continuity. All seismic interpretations were carried out on a UNIX seismic workstation using the GeoFrame ${ }^{\circledR}$ software package of Schlumberger.

\section{Integration of the seismic and well database}

Seismic-to-well ties were made using synthetic seismograms (Fig. 6). These were constructed by calculating an impedance curve from a sonic log, which was calibrated first with checkshot data to improve depth-time conversion. Where available, a density log was used as well. The impedance curve was convoluted with a theoretical seismic wavelet to form a synthetic seismogram. By visually comparing the synthetic seismogram to a reference trace from the seismic data, a seismic-to-well tie was made. This procedure was carried out using the 'synthetic'-module in GeoFrame ${ }^{\circledR}$.

The identified seismic sequence boundaries were subsequently noted and correlated between the well logs. Characteristic well log responses were identified for each sequence (Fig. 7).

\section{Dating of the seismic sequences}

The age of the seismic sequences was determined using the results of existing industrial micropaleonthological analyses. Since most of the micropaleonthological analyses date from the 1970s and 1980s, the biozonations had to be actualised using recent biozonations of the Chalk Group interval (King et al., 1989; Hardenbol et al., 1998; Bergen \& Sikora, 1999). 0ccasional reference was made to the biozonation of Koch (1977). Only the data of those wells was used that are positioned in an area where the seismic sequences are clearly developed and of which good synthetic seismograms could be constructed. Only first downhole occurrences (FDO's) of index foraminifera were used for age determination. This way, the possible effects of caving (i.e. younger rock material falling into the borehole from higher up) could be ruled out

As commented on by previous workers, biostratigraphical correlation in the Chalk Group is not a straightforward matter (Andersen et. al., 1990; Bergen \& Sikora, 1999; Bramwell et al., 1999; Vejbæk \& Andersen, 2003). This is even more the case in the study area where biostratigraphical data is scarce. Throughout this study the chronostratigraphical significance of the seismic sequence boundaries was therefore consistently given prevalence over indications from the well log or micropaleonthological dataset. It was assumed that the FD0 of a biomarker at a well location does not necessarily represent the regional last occurrence of the species, and therefore the whole age range was considered. Subsequent correlation was 


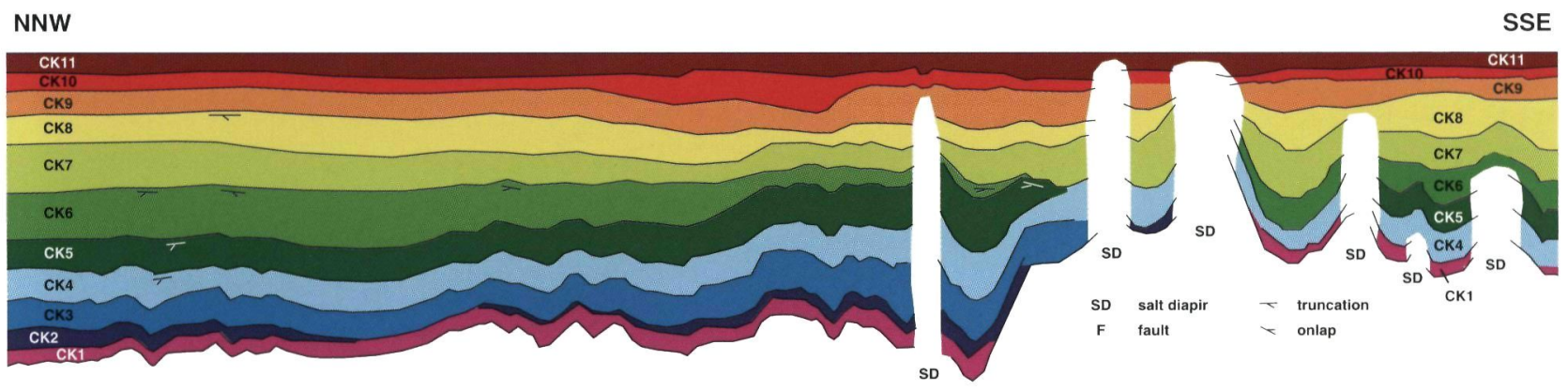

SGH

$\mathrm{AB}$

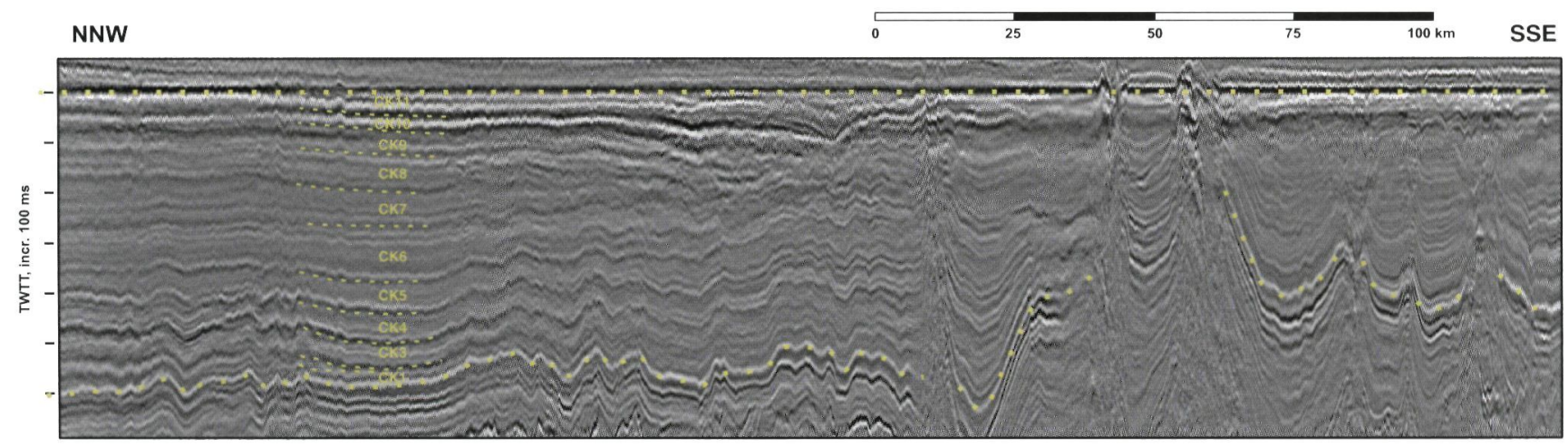

Fig. 5. Seismic section with interpreted intra-Chalk seismic sequences CK1 through CK11. The seismic sequences are defined by regionally correlated unconformities. The results of the seismic interpretation formed the basis of the lithostratigraphic subdivision presented in this paper. The section is flattened at the Top Chalk horizon and is NNW-SSE oriented, crossing the Schill Grund High (SGH) and Ameland Block (AB; Fig. 3 \& Fig. 4).

carried out assuming that the seismic sequences represent regional synchronous phases of chalk sedimentation. Sequences without any FDO were correlated based on their stratigraphic position. Sequence ages were assigned to formal stages and their common subdivisions (i.e. Early Maastrichtian) as much as possible. Unconformities separating subsequent sequences were assumed to represent short periods in time.

\section{Results}

\section{General seismic and well log response characteristics of the Chalk Group}

The lower and upper boundary of the Chalk Group form strong positive seismic reflectors throughout most of the study area (Figs 5 \& 6). In well logs, the Chalk Group is generally characterised by conspicuously low gamma-ray, high density and low sonic log values, compared to the enveloping siliciclastic sediments. The Chalk interval is the thickest around the Schill Grund High and southern Cleaver Bank High (Fig. 1, Fig. 2; Quadrants $\mathrm{G}, \mathrm{K}$ and $\mathrm{L}$ ). The Chalk is thin to absent in the southern Central Graben and Broad Fourteens Basin (Fig. 1, Fig. 2; Quadrants F, P \& Q).

Throughout the study area the seismic facies of the Chalk Group shows mostly parallel and continuous reflectors with varying reflector strength. Reflector strength appears to be specifically linked to seismic sequences, notwithstanding lateral variations. Sequence CK2, as well as the three upper sequences, CK9, CK10 and CK11 (Fig. E9, Fig. E10 and Fig. E11), generally show strong seismic amplitudes. In turn, the middle seismic sequences (CK3 through CK8) usually show low reflectivity.

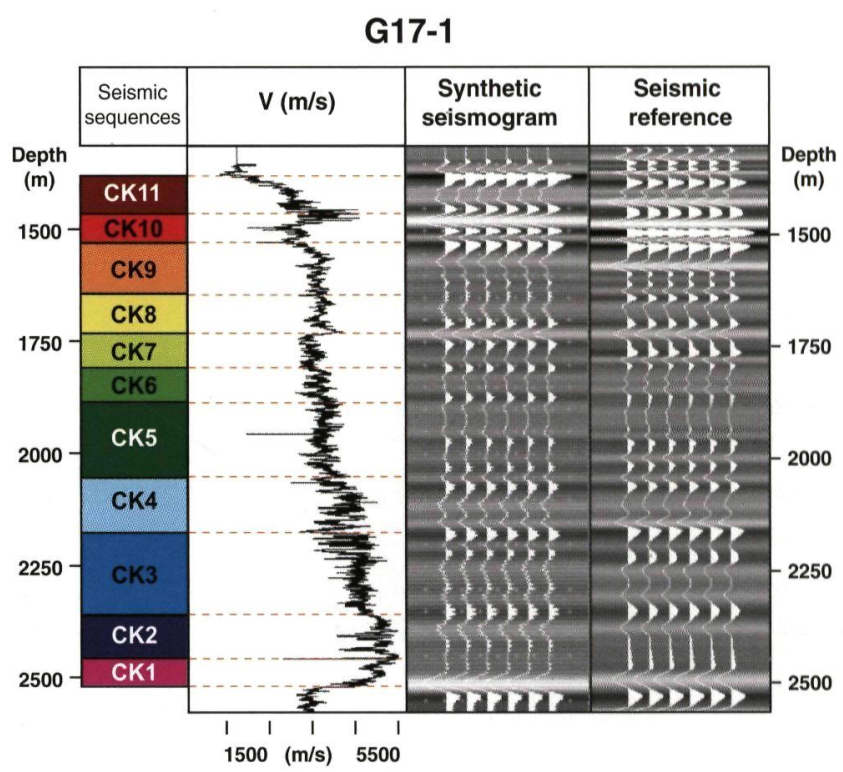

Fig. 6. Synthetic seismograms of well G17-1. Synthetic seismograms were used to tie the seismic to the well-log database. The location of G17-1 is indicated in Fig. 3. 


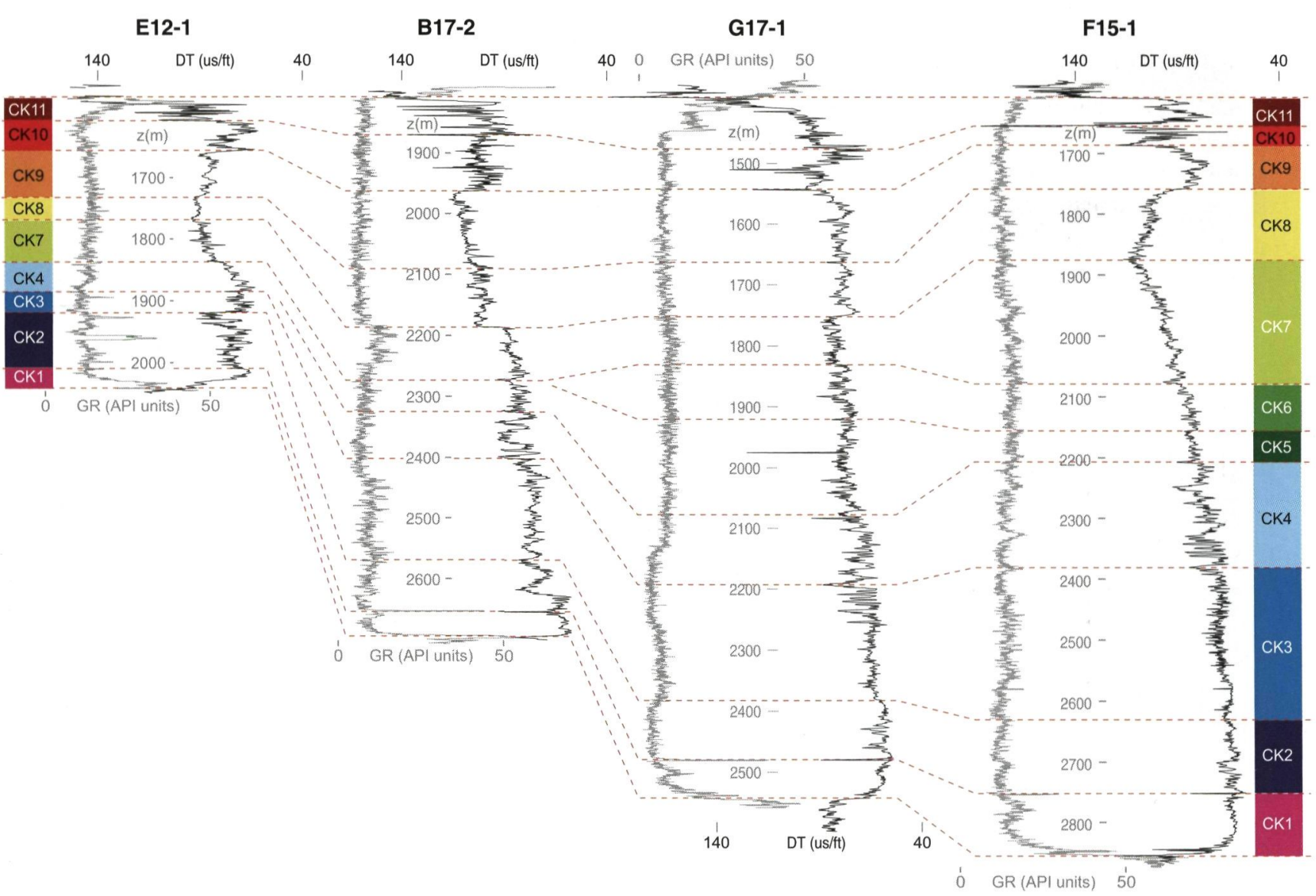

Fig. 7. Sonic log profile of wells D15-1, E12-1, B17-2, G17-1 and F15-1 (see Fig. 3 for location). Intra-Chalk seismic sequences CK1 to CK11 were tied to the well database using synthetic seismograms (Fig. 5). Using these results, a log correlation of the Chalk Group interval of 45 wells was made to support the seismic interpretation. The seismic sequences were subsequently dated with biostratigraphical data available in a selection of wells (Fig. 7).

This pattern is mirrored in the well log response to some extent. Particularly sequence CK10 and CK11 often show a highly serrated (i.e. with high-amplitude variations) log response (Fig. 6 \& Fig. 7).

Areas showing irregular or chaotic seismic reflectors occur predominantly where the Chalk is thinnest, especially along the Dutch Central Graben (in quadrants $G$ and B; Fig. 2). Furthermore, irregular reflectors outline a large NNW-SSE trending channel, approximately $100 \mathrm{~km}$ long (inside the study area) and about $10-20 \mathrm{~km}$ wide, in sequence CK9 of the Schill Grund High - Ameland Quadrant area (Fig. E9). Similar channels, although much smaller, are found in the Late Maastrichtian sediments (sequence CK10) of the Cleaver Bank High (northern part of quadrant K) and Elbow Split High (Fig. E10, Fig. 2).

\section{Description of the seismic sequences}

The Chalk Group in the Netherlands North Sea area was subdivided into eleven seismic sequences, named CK1 through CK11. The distribution of the sequences is outlined by time structure maps of the basal seismic sequence boundaries (Supplementary figures E1 through E11, in pdf). Fig. 8 shows an overview of the main biostratigraphical data. In this figure, an arrow indicates the relative stratigraphic position of the first downhole occurrence (FD0) of an index species within the seismic sequence in that well. The following sequences have been defined:

- CK1 (Cenomanian; Fig. E1). The basal seismic sequence of the Chalk succession represents the Cenomanian Texel Formation (Fig. 3; Van Adrichem Boogaert \& Kouwe, 1994). The sequence is generally developed as a single or double, parallel and continuous, weak seismic reflector. The conspicuous Plenus Marl Member (Fig. 3; Van Adrichem Boogaert \& Kouwe, 1994) forms the top of sequence CK1. In well logs, the Plenus Marl Member forms a distinct spike in gamma-ray, sonic and density logs (Fig. 6 \& Fig. 7). The Cenomanian age of CK1 is supported by the presence of the benthic foraminifera Gavelinella intermedia and Gavelinella cenomanica, as well as the planktonic foraminifera Rotalipora cushmani and Praeglobotruncana sp.

- CK2 (Turonian to Coniacian; Fig. E2). In the western and central part of the study area, this sequence is most clearly developed and consists of a set of, usually three, very highamplitude seismic reflector couplets. Sonic and density log intervals show a distinctly serrated log response character 
in these areas (e.g. E12-1 and G17-1; Fig. 6 \& Fig. 7). Seismic sequence CK2 is interpreted to be of Turonian age based on its stratigraphic position above CK1 and assuming early occurrences of the benthic foraminifera Stensioina granulata spp., Stensioina granulata granulata, and Gavelinella tourainensis. The biostratigraphy indicates that the sequence may extend well into the Coniacian.
- CK3 (Coniacian, Fig. E3). This sequence has the smallest remaining areal extent of all intra-Chalk sequences of the Dutch offshore. Where present, it generally shows lowamplitude, continuous to discontinuous parallel seismic reflectors. No biostratigraphic data are present for this sequence. A Coniacian age is inferred from its stratigraphic position.

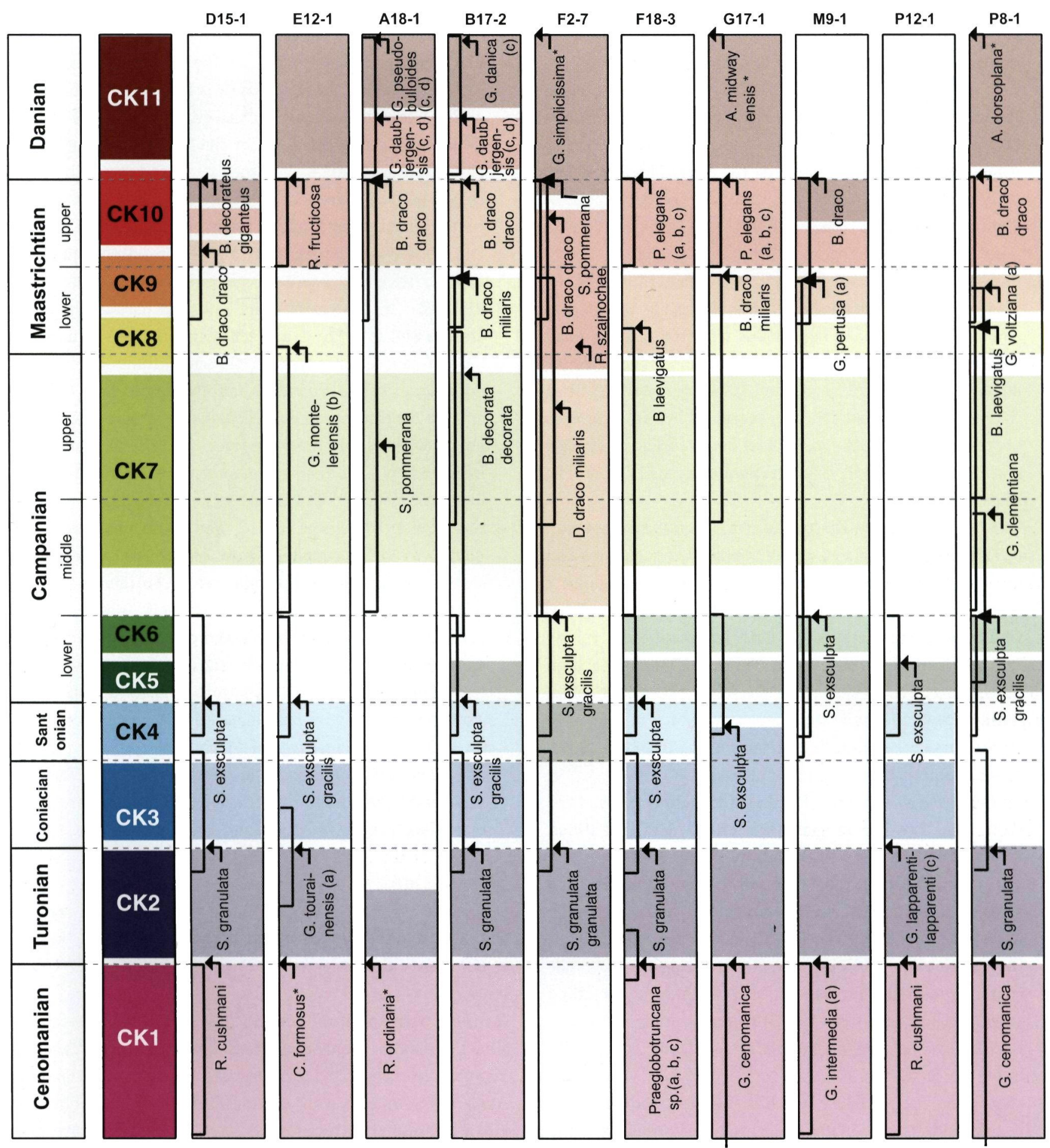

Fig. 8. Correlation of the biostratigraphical database used to date seismic sequences CK1 to CK11. Age ranges were predominantly compiled from Hardenbol et al. (1998b) for Upper Cretaceous to lower Paleocene index species, as well as King et al. (1989; species marked 'a'), Bergen \& Sikora (1999; species marked ' $b$ ') for Upper Cretaceous, Koch (1977; species marked ' $c$ ') for Upper Cretaceous to lower Paleocene and King (1989; species marked ' $d$ ') for lower Paleocene species. Of species marked ('*') the ages from the original biostratigraphic analysis were copied. 
- CK4 (Santonian; Fig. E4). Sequence CK4 generally shows continuous parallel reflectors, locally with high amplitudes. Where reflection strength is high, well log intervals of CK4 show high-amplitude variations in sonic and density log readings (e.g. in B17-2 and G17-1; Fig. 6 \& Fig. 7). Sequence CK4 is interpreted to be of Santonian age, assuming early occurrences of Stensioina exsculpta spp. and Stensioina exsculpta gracilis. The sequence may be lower Campanian, but the occurrence of similar biomarkers in the overlying sequences $\mathrm{CK} 5$ and CK6 makes this unlikely.

- CK5 (lower Campanian; Fig. E5). Thickness of this seismic sequence varies strongly (25 - $150 \mathrm{~ms})$ and seismic facies is characterised by generally low-amplitude, low frequency parallel and continuous reflectors. The age of CK5 is probably early Campanian, which is suggested by the occurrence of Stensioina exsculpta ssp. in $\mathrm{P} 12-1$ and the stratigraphic position of the sequence.

- CK6 (lower Campanian; Fig. E6). In the eastern part of the study area, this sequence is generally made up of lowamplitude, parallel and continuous reflectors. In the small subcrop in the P-quadrant, however, chaotic seismic reflectors are dominant. Seismic sequence CK6 is interpreted to be of (late) early Campanian age, as is suggested by the occurrence of Stensioina exsculpta spp. in M9-1 and Stensioina exsculpta gracilis in $\mathrm{P} 8-1$, and the stratigraphic position of the sequence.

- CK7 (middle to upper Campanian; Fig. E7). Seismic sequence CK7 has a larger areal extent than underlying sequences CK3 to CK6, and its base forms a marked angular unconformity throughout the study area. The sequence generally shows continuous parallel reflectors with low amplitudes in the northern part of the study area. Reflection strength is high in the south. Deposition of CK7 most likely took place during the middle and late Campanian, which is suggested by the presence of Gavelinella clementiana in P8-1 and the stratigraphic position of the sequence.

- CK8 (lower Maastrichtian; Fig. E8). Throughout most of the study area, the seismic facies is similar to CK7, with high amplitudes only encountered in quadrant D. However, in the northernmost part of the area chaotic and discontinuous parallel seismic reflectors, often with high amplitudes, dominate the seismic facies. The micropaleonthological evidence points to an Early Maastrichtian age (possibly starting in the Late Campanian), including presumed last occurrences of Bolivinoides draco miliaris in B17-2, Gavelinella montelerensis in E12-1 and Bolivinoides laevigatus in $\mathrm{P} 8-1$.

- CK9 (lower to upper Maastrichtian; Fig. E9). Sequence CK9 has the widest areal extent of all intra-Chalk sequences and shows marked variation in both seismic facies and amplitude strength. Throughout the study area, small zones of chaotic reflectors are encountered. In the east, chaotic reflectors are found along a NNW-SSE trending facies belt, outlining a large channel feature. An Early Maastrichtian age for this sequence is suggested in the east and south of the study area (wells F18-3, G17-1, M9-1 and P8-1), by the presumed last occurrences of Bolivinoides laevigatus, Bolivinoides draco miliaris, Gavelinella pertusa and Gavelinella voltziana. In the west and north of the study area, however, wells D15-1, A18-1 and B17-2 suggest a Late Maastrichtian age for this sequence, as suggested by the (presumed last) occurrence of Bolivinoides draco draco.

- CK10 (upper Maastrichtian, locally to lower Danian; Fig. E10). The seismic facies of $\mathrm{CK} 10$ is less variable than that of CK9, consisting almost exclusively of continuous parallel reflectors. Throughout most of the east and southernmost part of the study area, amplitude strength is generally high, compared to low amplitudes in the remaining area. Indications of small channels are found in quadrants A and K. Sonic and density logs generally show highly serrated readings in CK10, particularly where seismic reflectivity is high (Fig. 5 \& Fig. 6). In the eastern and southern part of the study area, as well as in E12-1, a late Maastrichtian age is suggested by the last occurrences of the planktonic foraminifera Racemiguembelina fructicosa and Pseudotextularia elegans, and the benthic foraminifera Bolivinoides draco draco. In the north of the study area, however, an Early Danian age is indicated by Globoconusa daubjergensis (A18-1 and B17-2).

- CK11 (Danian; Fig. E11). This seismic sequence represents the Ekofisk Formation (Fig. 3; Van Adrichem Boogaert \& Kouwe, 1994). Throughout most of the study area, CK11 shows low-amplitude, parallel and continuous seismic reflectors. In contrast, reflection strength is very high in parts of the large subcrop in the east. In the sonic and density logs, this sequence shows very strong, high frequency (meter scale), variations (Fig. 5 \& Fig. 6). In most of the wells, a Danian age is suggested for CK11, including last occurrences of Globorotalia pseudobulloides, Globoconusa daubjergensis and associated species. However, it is unclear when the onset of the CK11 depositionary phase took place exactly.

\section{Discussion}

\section{The significance of seismic stratigraphy in the Chalk Group}

The basic assumption of seismic stratigraphy is that seismic reflections follow depositional and erosional surfaces and are therefore timelines that can be used as chronostratigraphic markers (Vail et al., 1977b; Bertram \& Milton, 1996). Following this assumption, unconformities were mapped to arrive at a meaningful stratigraphical subdivision of the Chalk Group interval, despite the absence of a sufficiently detailed micropaleonthological dataset. The chronostratigraphic significance of seismic reflections has been tested by Eberli et al (2002), 
who dated seismic sequence boundaries using biostratigraphical data from several cores taken during the BDP (Bahamas Drilling Project) and ODP (0cean Drilling Program) projects. The authors prove that seismic reflections marking seismic sequence boundaries, that can be traced across several facies belts from the top of the Great Bahama Bank to the basin of the Florida Straits, are in fact constant in age.

An important aspect of the seismic stratigraphical concept is the notion that as relative sea-level variations result in landward or seaward shifts of depositional environments, a set of specific sedimentary units is formed that can be identified in seismic data (Vail et al., 1977a). Such indicative sequences cannot be identified in pelagic environments, making it impossible to reconstruct a sequence stratigraphic scheme of the Chalk Group (Bramwell et al., 1999). Therefore, a more general allostratigraphical subdivision is presented in this paper, following Bramwell et al. (1999). In this approach sedimentary rock units are purely defined by their boundary unconformities rather than their sedimentary make-up.

The seismic sequence boundaries mapped in this study are identified by seismic reflector terminations, indicating unconformities in the stratigraphic record (Mitchum et al, 1977b). In the Upper Cretaceous chalks, reflector terminations are almost exclusively found where the sea floor was uplifted at a certain stage during deposition. However, large areas exist in the study area where such features are not evident. Here, the seismic sequence boundaries were correlated along parallel reflections, representing 'correlative conformities' sensu Mitchum (1977a).

It is important to note that the sequence boundaries presented in this paper, although the most pronounced and most clearly correlatable in the studied seismic data, are by no means the only hiatuses present in the Chalk. Many smaller hiatuses are evident from incidental reflector terminations and shifts in sonic and density logs.

\section{Review of the micropaleonthological data}

The two processes that have a detrimental effect on age determinations, as carried out in this study, are 'caving' and resedimentation. The effects of caving were discussed in the biostratigraphy paragraph of the 'Dataset and methods' section. Resedimentation is a common feature of the Chalk in (syndepositional) tectonically active areas such as the Central Graben (Scholle, 1977; Hatton, 1986; Kennedy, 1987). It has the effect of introducing older sediment into younger layers, leading to an overestimation of age. Resedimentation is difficult to prove and can only be assumed in wells in which consistently older ages are determined for each seismic sequence, compared to the surrounding wells. F2-7 shows older ages for most of the seismic sequences (Fig. 8). As this well is located in the Dutch Central Graben, where chaotic seismic reflectors indicate massive sediment reworking, resedimentation offers the best explanation for these higher ages.
Following the definition of Van Adrichem Boogaert \& Kouwe (1994), the top of the Cenomanian sequence CK1 is placed at the well log 'spike' that represents the Plenus Marl Member (Fig. 7). Bergen \& Sikora (1999) note that Rotalipora cushmani, which indicates the Cenomanian according to King et. al. (1989), is very rare. However, this species is found in both wells P12-1 and D15-1, demonstrating its usefulness in identifying the Texel Formation in the study area. Praeglobotruncana sp. extends into the Turonian (King et. al., 1989; Bergen \& Sikora, 1999), but is thought to represent the Cenomanian in F18-3 based on the position of the Plenus Marl well log marker. This marker was also used to determine the age of CK1 in B17-2, where no key species were found. In wells D15-1, B17-2, F18-3 and P8-1, Stensioina granulata is not specified (i.e. S. $g$. granulata, S. g. polonica or other). It is important to note that the FDO of $S$. granulata in these wells may represent an age ranging from Late Turonian (S. g. humilis) to Early Santonian (S. g. granulata; King et. al., 1989; Bergen \& Sikora, 1999). Furthermore, S. g. polonica, of Early to Middle Santonian age according to King et. al. (1989), is specifically identified as a 'misleading index' by Bergen \& Sikora (1999), based on its diachroneity even within the Valhall study area. This may also explain the relatively high age of the top of CK3 in F18-3. Similarly, Stensioina exsculpta is not specified (i.e. S. e. exsculpta or S. e. gracilis) in wells D15-1, F18-3, G17-1, M9-1 and P12-1. However, Bergen \& Sikora (1999) stated that these subspecies are commonly associated and both extend into the early Middle Campanian.

The onset of CK7 post-dates the last occurrence of the benthic foraminifera $S$. exsculpta spp. and $S$. exsculpta gracilis (the latest occurrence is at the top of CK6 in M9-1 and P8-1). As the onset of $\mathrm{CK} 7$ also post-dates a very strong uplift and erosion phase, likely to represent a considerable amount of time, it is presumable that deposition did not start until the Middle Campanian. The occurrence of Stensioina pommerana in the lower section of CK7 in well A18-1, suggests that this represents an early occurrence of this Early Campanian to Late Maastrichtian benthic foraminifera (Hardenbol et. al., 1998). In F2-7, the occurrence of Bolivinoides draco miliaris is probably not younger than Late Campanian because of the shallower FDO of Reussella szajnochae, which indicates the end of the Campanian (Hardenbol et. al., 1998). In M9-1, at the top of CK1, Bolivinoides draco remains unspecified (i.e. B. d. draco or B. d. miliaris) but its stratigraphic position suggests that this represents the Late Maastrichtian (B. d. draco; Hardenbol et. al., 1998).

\section{Towards an improved lithostratigraphic subdivision of the Chalk Group in the Netherlands North Sea area}

To improve the formal subdivision of the Chalk Group in the Netherlands North Sea area (Van Adrichem Boogaert \& Kouwe, 1994), the present dataset was correlated to the surrounding 
areas, i.e. the UK, Danish and Norwegian offshore areas. This allowed for the integration of the stratigraphic definitions throughout the North Sea area, linking the Netherlands offshore to the Central North Sea where the Chalk Group has been studied extensively. Based on this integration, the authors of this paper suggest a revision of the formal lithostratigraphic scheme, recognising Tor Formation and Herring Formation equivalents in the Netherlands offshore.

The Cenomanian Texel/Hidra Formation and the directly overlying Plenus Marl Member and its equivalents (i.e. Black Bend Bed and lower part of the Blødoks Formation) generally form an easily recognisable and correlatable interval. The Texel Formation equivalent seismic sequence CK1 could be traced throughout the study area, supporting the existing subdivision (Fig. 5 \& Fig. E1).

The Turonian to Campanian is defined as the Hod Formation in the Norwegian and Danish (Hod F. equivalent) offshore sectors (Lieberkind et al., 1982; Isaksen \& Tonstad, 1989). In the UK sector, this interval is subdivided into a lower to middle Turonian Herring Formation and an upper Turonian to lower Maastrichtian (locally, upper Campanian)
Mackerel Formation (Johnson \& Lott, 1993). A marked similarity exists between the high-amplitude sonic log response variations of the Herring Formation and the Turonian seismic sequence CK2 of the study area (Fig. 7 \& Fig. 9). Furthermore, progressively downward increasing acoustic velocities, characteristic for the Mackerel Formation according to Johnson \& Lott (1993), are also observed in seismic sequences CK3 to CK7. These observations support the subdivision of a separate Turonian formation in the Netherlands North Sea sector. However, the informal subdivision of the Hod Formation into three members in the Norwegian offshore cannot be recognised in our study area (Fig. 9).

The Maastrichtian (locally, upper Campanian to Maastrichtian) interval forms a separate formation in the British, Norwegian and Danish North Sea sectors. Based on log response characteristics, the Tor Formation is defined by markedly higher acoustic velocities and slightly lower and more constant gamma-ray readings, compared to the formations above and below (Isaksen \& Tonstad, 1989; Johnson \& Lott, 1993). The Tor Formation can be readily correlated to the Maastrichtian section (sequences CK8, CK9 and CK10) of well G17-1 (Fig. 9).
30/19A-4 (UK)

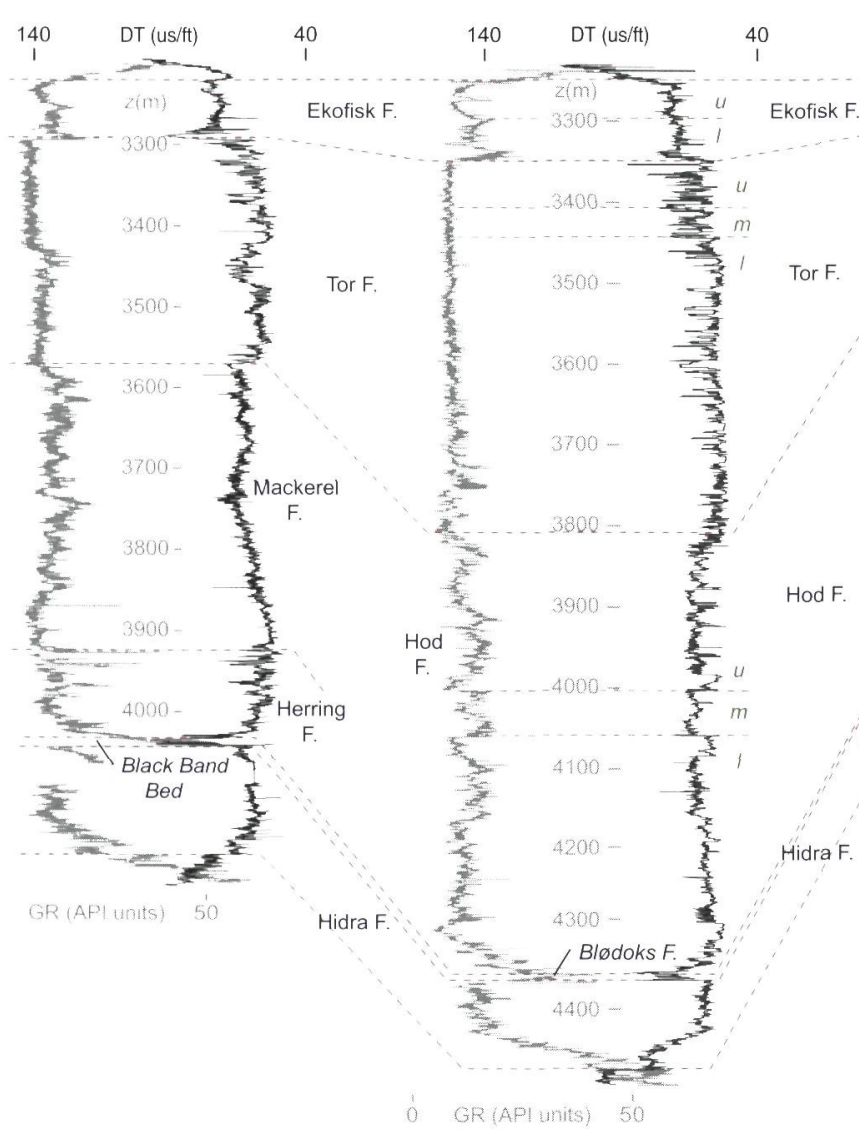

$\operatorname{Kim}(\mathrm{DK})$

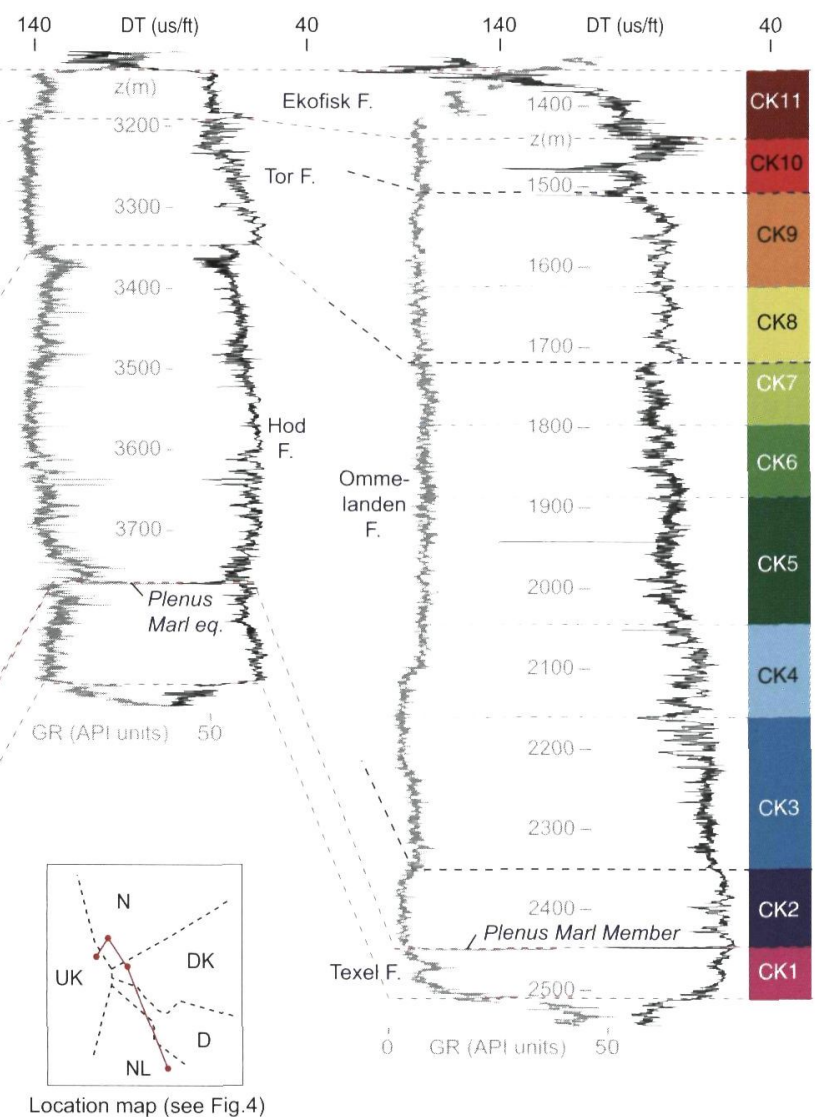

Fig. 9. Correlation between the Dutch well G17-1 and wells from the Danish, Norwegian and British North Sea sectors. The red lines delineate the subdivision according to the existing lithostratigraphic schemes (Fig. 3; Lieberkind et al., 1982; Isaksen \& Tonstad, 1989; Johnson \& Lott, 1993; Van Adrichem Boogaert \& Kouwe, 1994; Surlyk et al., 2003). Informal subdivisions of the Hod, Tor and Ekofisk Formations in the Norwegian sector, described by Isaksen \& Tonstad (1989), are indicated by green lines. The seismic sequence boundaries described in this paper are outlined in light and dark blue. 
However, this formation is not so easily identified in other wells in the study area although some observations can be made. The base of sequence CK8 often points to a marked break from the downward increasing velocity trend observed in the sequences below, sometimes associated with a distinct shift in acoustic velocity. Acoustic velocity trends in CK8 vary greatly troughout the area and can show upwardly increasing, as well as decreasing, velocities. CK9 shows a similar variation but with generally higher velocities (Fig. 7 \& Fig. 9). In contrast, seismic sequence $\mathrm{CK} 10$ shows a very distinct serrated sonic log pattern throughout the study area. This log pattern is recognised in the surrounding areas as well and represents allochthonous deposits, i.e. slumps, slide sheets, debris flows (Isaksen \& Tonstad, 1989; Johnson \& Lott, 1993; Surlyk et al., 2003). Informal middle and upper Tor Members have been defined in the Norwegian offshore based on the same feature (Isaksen \& Tonstad, 1989).

The above suggests that a subdivision of a separate, Tor equivalent, formation can be made in the Netherlands offshore area. Furthermore, the distinct sonic log character of CK10 supports a further separation of the Tor Formation equivalent into a lower and upper member. Although some indications for lower gamma-ray readings, indicative of cleaner chalks, can be found in the Tor Formation equivalent interval (e.g. in B17-2 and possibly G17-1), this does not appear to be a defining characteristic in the study area.

Seismic sequence CK11 represents the Danian Ekofisk Formation, as defined by Van Adrichem Boogaert \& Kouwe (1994) in the Netherlands North Sea area. This formation is informally subdivided into two members in the Norwegian and Danish North Sea sectors. The lower unit is characterised by low porosities and higher terrigenous clay content and is referred to as the 'Ekofisk tight zone' by Isaksen \& Tonstad (1989). The upper unit consists of cleaner chalks with higher porosities. A similar subdivision is described in the UK North Sea area by Johnson \& Lott (1993), who do not assign members in this formation. In wells $30 / 19 \mathrm{~A}-4$ (UK) and 1/3-1 (N) this division is particularly evident in the gamma-ray logs (Fig. 9). A bipartite subdivision of the sonic log can generally be made in the Netherlands offshore as well. However, as the sonic log character of the Danian interval varies strongly throughout the area, this does not seem to support a formal subdivision of the Ekofisk Formation.

\section{Conclusions}

- To arrive at a more detailed lithostratigraphic subdivision of the Chalk Group in the Netherlands North Sea area, a seismic stratigraphic analysis of the interval was carried out on a regional 2D and 3D seismic dataset. A subdivision into eleven seismic sequences was made that was based on the identification and mapping of unconformities throughout the seismic grid. The seismic sequence boundaries served as the main chronostratigraphic markers. These were noted and correlated in wireline logs of 45 wells, after which biostratigraphical data from a selection of these wells was used to date the sequences.

- The seismic sequences are interpreted to be of Cenomanian (CK1), Turonian (CK2), Coniacian (CK3), Santonian (CK4), Early Campanian (CK5; CK6), Middle to Late Campanian (CK7), Early Maastrichtian (CK8; CK9), Late Maastrichtian (CK10) and Danian (CK11) age.

- With the exception of syn-depositionally inverted areas such as the Dutch Central Graben, the seismic sequences generally show parallel and continuous reflectors throughout the study area. Reflector strenght varies, but is specifically linked to seismic sequences, notwithstanding lateral variations. Sequence $\mathrm{CK} 2$, as well as the three upper sequences (CK9, CK10 and CK11) generally show strong seismic amplitudes. In turn, the middle seismic sequences (CK3 through CK8) usually show low reflectivity. This pattern is mirrored in the well log response to some extent. Sequence CK2, and particularly CK10 and CK11, often show a highly serrated sonic and density log response (i.e. showing high-amplitude log response variations).

- The seismic sequences recognised in this study were compared with formal lithostratigraphic units defined in the Chalk Group in the surrounding North Sea sectors. The serrated log response characters of sequences CK2 and CK10 in particular could be correlated to similar log patterns described in the British, Danish and Norwegian North Sea sectors. Based on this comparison, a revision of the formal lithostratigraphic scheme, recognising Tor Formation and Herring Formation equivalents, is suggested for the Netherlands North Sea area.

\section{References}

Andersen, C., Clausen, C. K., Möller, C., Nygaard, E. \& Stouge, S., 1990. Intra-chalk Study, EFP-87: A Multidisciplinary Breakdown. Geological Survey of Denmark (Copenhagen): $30 \mathrm{pp}$.

Anderson, J.K., 1999. The capabilities and challenges of the seismic method in chalk exploration. In: Fleet, A.J. \& Boldy, S.A.R. (eds): Petroleum Geology of Northwest Europe: proceedings of the 5th Conference. The Geological Society of London (London): 939-949.

Bergen, J.A. \& Sikora, P.J., 1999. Microfossil diachronism in southern Norwegian North Sea chalks; Valhall and Hod fields: In: Jones, R.W. \& Simmons, M.D. (eds): Biostratigraphy in production and development geology, Geological Society Special Publications 152, The Geological Society of London (London): 85-111.

Bertram, G.T. \& Milton, N.J., 1996. Seismic stratigraphy. In: Emery, D. \& Meyers, K.J. (eds): Sequence Stratigraphy. Blackwell Science (0xford): $297 \mathrm{pp}$.

Bless, M.J.M., Dusar, M. \& Streel, M., 1987. Some aspects of the Late Cretaceous in NW Europe. Annales de la Société Géologique de Belgique 109: 84 pp. 
Bramwell, N.P., Caillet, G., Meciani, L., Judge, N., Green, A. \& Adam, P., 1999. Chalk exploration, the search for a subtle trap. In: Fleet, A.J. \& Boldy, S.A.R. (eds): Petroleum Geology of Northwest Europe: proceedings of the 5th Conference. Geological Society of London (London): 911-937.

Brasher, J.E. \& Vagle, K.R., 1996. Influence of lithofacies and diagenesis on Norwegian North Sea chalk reservoirs. AAPG Bulletin 80: 746-769.

Campbell, S.J.D. \& Gravdal, N., 1995. The prediction of high porosity chalks in the East Hod Field. Petroleum Geoscience 1: 57-69.

De Jager, J., 2003. Inverted basins in the Netherlands, similarities and differences. Netherlands Journal of Geosciences/Geologie en Mijnbouw 82: 355-366.

Dronkers, A.J. \& Mrozek, F.J., 1991. Inverted basins of the Netherlands. First Break 9: 409-425.

Eberli, G.P., Anselmetti, F.S, Kroon, D., Sato, T.\& Wright, J.D., 2002. The chronostratigraphic significance of seismic reflections along the Bahamas Transect. Marine Geology 185: 1-17.

Felder, W.M., 1975. Lithostratigraphie van het Boven-Krijt en het Dano Montien in Zuid Limburg en het aangrenzende gebied. In: Zagwijn, W.H. \& Van Staalduinen, C.J. (eds.): Toelichting bij geologische overzichtskaarten. Rijks Geologische Dienst (Haarlem): 63-72.

Felder, P.J., Bless, M.J.M., Demyttenaere, R., Dusar, M., Meessen, J.P.M.T. \& Robaszynski, F., 1985. Upper Cretaceous to Early Tertiary deposits (Santonian-Paleocene) in Northeastern Belgium and South Limburg (the Netherlands) with reference to the Campanian-Maastrichtian. Belgian Geological Survey Professional Paper 214: 151 pp.

Gras, R. \& Geluk, M., 1999. Late Cretaceous - Early Tertiary sedimentation and tectonic inversion in the southern Netherlands. Geologie en Mijnbouw 78: 1-19.

Hancock, J.M., 1975. The Petrology of the Chalk. Proceedings of the Geological Association 86: 499-535.

Hardenbol, J., Thierry, J., Farley, M.B., Jacquin, T., De Graciansky, P.C. \& Vail, P., 1998. Chart 3: Cenozoic Biochronostratigraphy and Chart 5: Cretaceous Biochronostratigraphy. In: De Graciansky, P.C., Hardenbol, J., Jacquin, T. \& Vail, P. (eds): Mesozoic and Cenozoic Sequence Stratigraphy of European Basins, SEPM Special Publication 60. Society of Economic Paleontologists and Mineralogists (Tulsa): $786 \mathrm{pp}$.

Hatton, I.R., 1986. Geometry of allochtonous Chalk Group members, Central Through, North Sea. Marine and Petroleum Geology 3: 79-98.

Herngreen, G.F.W., Eillebrecht, A.J., Gortemaker, R.E., Remmelts, G., Schuurman, H.A.H.M. \& Verbeek, J.W., 1996. Upper Cretaceous Chalk Group stratigraphy near the isle of Texel, the Netherlands (a multidisciplinary approach). Medelingen Rijks Geologische Dienst 56: 63 pp.

Isaksen, D. \& Tonstad, K., 1989. A revised Cretaceous and Tertiary lithostratigraphic nomenclature for the Norwegian North Sea. NPD Bulletin 5: 59 pp.

Johnson, H. \& Lott, G.K., 1993. Lithostratigraphic nomenclature of the UK North Sea Volume 2, Cretaceous of the Central and Northern North Sea. British Geological Survey (Nottingham): 169 pp.

Kennedy, W.J., 1987. Sedimentology of Late Cretaceous - Palaeogene Chalk reservoirs, North Sea Central Graben. In: Brooks, J. \& Glennie, K. (eds): Petroleum Geology of North West Europe. Graham \& Trotham (London): 469- 481.

King, C., 1989. Cenozoic of the North Sea. In: Jenkins, D.G. \& Murray, J.W. (eds): Stratigraphic atlas of fossil foraminifera. Ellis Horwood (Chichester): 418-490.
King, C., Bailey, H.W., Burton, C. \& King, A.D., 1989. Cretaceous of the North Sea. In: Jenkins, D.G. \& Murray, J.W. (eds): Stratigraphic atlas of fossil foraminifera. Ellis Horwood (Chichester): 372-418.

Koch, W., 1977. Biostratigraphie in der Oberkreide und Taxonomie von Foraminiferen. In: Baldschuhn, R., Jaritz, W. \& Koch, W. (eds.): Stratigraphie der Oberkreide in Nordwestdeutschland (Pompeckjsche Scholle). Geologisches Jahrbuch A38: 11-123.

Lieberkind, K., Bang, I., Mikkelsen, N. \& Nygaard, E., 1982. Late Cretaceous and Danian limestone. In: Michelsen, 0.0. (ed.): Geology of the Danish Central Graben, Series B, No. 8. Geological Survey of Denmark (Copenhagen): 49-62.

Mitchum, jr., R.M, 1977. Glossary of Terms used in Seismic Stratigraphy. In: Payton, C. E. (ed.): Seismic Stratigraphy - Applications to hydrocarbon exploration, AAPG Memoir 26. American Association of Petroleum Geologists (Tulsa): 205-212.

Mitchum, jr., R.M, Vail, P.R. \& Sangree, J.B., 1977. Seismic stratigraphy and Global Changes of Sea Level, Part 6: Stratigraphic Interpretation of Seismic Reflection Patterns in Depositional Sequences. In: Payton, C. E. (ed.): Seismic Stratigraphy - Applications to hydrocarbon exploration, AAPG Memoir 26. American Association of Petroleum Geologists (Tulsa): 117-135.

Mitchum, jr., R.M. Vail, P.R., 1977. Seismic stratigraphy and Global Changes of Sea Level, Part 7: Seismic Stratigraphic Interpretation Procedure. In: Payton, C.E. (ed.): Seismic Stratigraphy - Applications to hydrocarbon exploration, AAPG Memoir 26. American Association of Petroleum Geologists (Tulsa): 135 145.

Nygaard, E., Andersen, C, Möller, Clausen, C.K. \& Stouge, S., 1989. Integrated multidisciplinary stratigraphy of the Chalk Group: an example from the Danish Central Through In: Chalk: Proceedings of the International Chalk Symposium held at Brighton Polytechnic on 4-7 September 1989. Thomas Telford Ltd. (London): 195-201.

Ogg, J.G., Agterberg, F.P. \& Gradstein, F.M., 2004. The Cretaceous Period. In: Gradstein, F.M., 0gg, J.G. \& Smith, A.G. (eds): A Geological Time Scale 2004. Cambridge University Press (Cambridge): $589 \mathrm{pp}$.

Rider, M.H., 1996. The geological interpretation of well logs. Whittles Publishing (London): $245 \mathrm{pp}$.

Scholle, P.A., 1977. Chalk diagenesis and its relation to petroleum exploration; oil from chalks, a modern miracle?. AAPG Bulletin 61: 982-1009.

Surlyk, F., Dons, T., Clausen, C.K. \& Highham, J., 2003. Upper Cretaceous. In: Evans, D., Graham, C., Armour, A. \& Bathurst, P. (eds): The Millenium Atlas: Petroleum Geology of the Central and Northern North Sea. The Geological Society of London (London): 213-233.

Vail, P. R., Mitchum, jr., R.M. \& Thomson III, S., 1977. Seismic stratigraphy and Global Changes of Sea Level, Part 3: Relative Changes of Sea Level from Coastal Onlap. In: Payton, C. E. (ed.): Seismic Stratigraphy - Applications to hydrocarbon exploration, AAPG Memoir 26. American Association of Petroleum Geologists (Tulsa): 99-117.

Vail, P.R., Todd, R.G. \& Sangree, J.B., 1977. Seismic stratigraphy and Global Changes of Sea Level, Part 5: Chronostratigraphic Significance of Seismic Reflections. In: Payton, C.E. (ed.): Seismic Stratigraphy - Applications to hydrocarbon exploration, AAPG Memoir 26. American Association of Petroleum Geologists (Tulsa): 99-117. 
Van Adrichem Boogaert, H.A. \& Kouwe, W.F.P. (eds), 1994. Stratigraphic nomenclature: section H - Upper Cretaceous and Danian (Chalk Group), Mededelingen Rijks Geologische Dienst 50, Rijks Geologische Dienst (Haarlem).

Van der Molen, A.S., Dudok van Heel, H.W., Wong, Th.E., 2005, The influence of tectonic regime on chalk deposition: examples of the sedimentary development and 3D-seismic stratigraphy of the Chalk Group in the Netherlands offshore area. Basin Research 17: 63-81.

Van Wijhe, D.H., 1987. Structural evolution of inverted basins in the Dutch offshore. Tectonophysics 137: 171-219.

Vejbæk, O.V. \& Andersen, C., 2003. Post mid-Cretaceous inversion tectonics in the Danish Central Graben - Regionally synchronous tectonic events? Bulletin of the Geological Society of Denmark 49: 129-144.

Ziegler, P.A., 1990. Geological atlas of western and central Europe. Shell Internationale Petroleum Maatschappij (The Hague): 237 pp. 